\title{
Üniversite Öğrencilerinin Bilişsel Duygu Düzenlemelerinde Çocukluk Örselenmeleri ve Otomatik Düşüncelerin Yordayıcı Rolü
}

\author{
The Predictive Role of Childhood Trauma and Automatic Thoughts in \\ Cognitive Emotion Regulation of University Students \\ Hasan SARICI ${ }^{1}$ Özlem TAGAY ${ }^{2}$
}

• Geliş Tarihi: 15.03.2019 • Kabul Tarihi: 23.09.2019 • Çevrimiçi Yayın Tarihi: 23.09.2019

\section{$\ddot{O} \mathbf{z}$}

$\mathrm{Bu}$ araştırmada, üniversite öğrencilerinin bilişsel duygu düzenlemelerinde çocukluk örselenme yaşantılarının ve otomatik düşüncelerinin yordayıcı rolünü incelemek amaçlanmıştır. Araştırmanın çalışma grubunu 2017-2018 eğitim öğretim yılında farklı fakültelerde öğrenim gören 652 üniversite öğrencisi oluşturmaktadır. Araştırmanın verileri, Onat ve Otrar (2010), tarafindan Türkçe'ye uyarlanan "Bilişsel Duygu Düzenleme Ölçeği”, Kaya (2014), tarafindan Türkçe'ye uyarlanan "Çocukluk Dönemi Örselenme Yaşantıları Ölçeği Kısa Formu”, Aydın ve Aydın (1990), tarafindan Türkçe'ye uyarlanan “Otomatik Düşünceler Ölçeği ile toplanmıştır. Verilerin analizinde, IBM SPSS ve AMOS programları kullanılmıştır. Elde dilen verilerin analizinde yüzde, frekans, aritmetik ortalama, standart sapma, ve regresyon analizi kullanılmıştır. Yapılan analizler sonucunda, çocukluk örselenme yaşantılarının ve otomatik düşüncelerin bilişsel duygu düzenlemenin anlamlı birer yordayıcıları olduğu sonucuna varılmıştır.

Anahtar sözcükler: Bilişsel duygu düzenleme, çocukluk örselenme yaşantıları, otomatik düşünceler.

Atıf:

Sarıcı, H., ve Tagay, Ö. (2020). Üniversite öğrencilerinin bilişsel duygu düzenlemelerinde çocukluk örselenmeleri ve otomatik düşüncelerin yordayıcı rolü. Pamukkale Üniversitesi Eğitim Fakültesi Dergisi, 49, 46-66. doi: 10.9779/pauefd.540635.

\footnotetext{
* Bu araştırma Burdur Mehmet Akif Ersoy Üniversitesi’nde Yüksek Lisans Tezi olarak tamamlandı ve Bilimsel Araştırma Projeleri Koordinatörlüğü tarafindan 0495-YL-18 nolu Bilimsel Araştırma Projesi olarak 17.01.201807.09.2018 tarihlerin arasında desteklenmiştir.

${ }^{1}$ Araş. Gör. Hasan SARICI, Orta Doğu Teknik Üniversitesi, hasansarici3@hotmail.com

${ }^{2}$ Doç. Dr. Özlem TAGAY, Burdur Mehmet Akif Ersoy Üniversitesi, ozlemtagay@,gmail.com
} 


\begin{abstract}
The aim of this research is to investigate the predictive role of childhood traumatic experiences and automatic thoughts on university students' cognitive emotion regulation. The study group of this research consists of 652 university students who studies at Zonguldak Bülent Ecevit University in 2017-2018 academic year. Research data was collected via Cognitive Emotion Regulation Scale which is developed by Onat and Otrar (2010), Childhood Traumatic Experiences Scale Short Form which is developed by Kaya (2014) and Automatic Thoughts Scale which is developed by Aydın and Aydın (2009). In data analysis, IBM SPSS and IBM AMOS programs were used. Percentage, frequency, arithmetic mean, standard deviation, and regression analysis were used in the analysis of obtained data. As a result of the analyzes, it was concluded that childhood traumatic experiences and automatic thoughts are significant predictors of cognitive emotion regulation.
\end{abstract}

Keywords: Cognitive emotion regulation, childhood traumatic experiences, automatic thoughts.

Cited:

Sarıc1, H., \& Tagay, Ö. (2020). The predictive role of childhood trauma and automatic thoughts in cognitive emotion regulation of university students. Pamukkale Üniversitesi Eğitim Fakültesi Dergisi, 49, 46-66. doi: 10.9779/pauefd. 540635. 


\section{Giriş}

İnsan, dünya üzerinde düşünme kapasitesine sahip tek canlı türüdür. Sahip olunan bu kapasite sayesinde diğer canlılarla iletişime geçilir. Sosyalleşme olarak adlandırılan bu etkileşim bir takım duyguların ortaya çıkmasına sebep olur. Duygular, insanların psikolojik ve sosyal açıdan gelişiminin temel belirleyicilerindendir. Davranışsal tepkiler, karar verme, hatırlama gibi günlük yaşam becerilerinde ve insanlarla etkileşime geçme süreçlerinde duygulardan destek alınır. İnsanın sosyalleşmesinde temel unsurlardan biri olan duygular yaşanan olaylara göre pozitif veya negatif yönde etkilenmektedir. Edinilen tecrübeye olumlu duygularla yaklaşım ile olumsuz duygularla yaklaşım arasında sonuçlar açısından farklılıklar vardır (Gross, 1998). İnsanların yaşantıları kişiden kişiye farklılık gösterdiği için duygulanma şekilleri de benzer şekilde farklılaşmaktadır. Bir insan doğumdan itibaren edindiği tecrübelerle kendisini geliştirmekte ve karakterini oluşturmaktadır.

Ergenlik öncesi dönemde ebeveyn tutumu, ergenlikte yaşanılan çalkantılı duygu dünyası ve hormonsal dengesizlik gibi belirleyici dönemlerde insanların sağlıklı bir şekilde süreci tamamlaması duygusal açıdan sağlıklı bireylerin topluma dahil olmasını sağlamaktadır. Ancak örseleyici çocukluk yaşantıları, olumsuz örnek teşkil edecek ebeveyn tutumları, duyguların bastırılması, dini zorlamalar, yaşamdaki monotonluk, otomatik düşünceler vb. sebeplerden dolayı insanlar duygusal gelişimlerini sağlıklı bir şekilde sürdüremeyebilir (Çelik ve Kocabıyık, 2014). İnsanın duygu dünyası sosyal, bilişsel ve fizyolojik faktörlerden etkilenebilen ve bunun sonucunda işlevselliğini belirleyen bir yapıya sahiptir. Bahsi geçen etkenlerin yalnızca duygusal gelişimin yönünü belirlemesi söz konusu değil ayrıca duruma özgü duyguların düzenlenme becerileriyle de doğrudan alakalıdır. Bireyin kişiler arası iletişim becerilerinden, kariyer gelişimine kadar birçok yaşam durumunu etkileyen duygu düzenleme becerilerinin geçmiş tecrübelerin birikimiyle içinde bulunulan düzeye ulaştığı göz önüne alınacak olursa sözü edilen çocukluk döneminden getirilen birikimin irdelenmesi son derece önemlidir çünkü insanların zihinsel ve fiziksel gelişiminin temelleri o dönemlerde atılır (Orçan, 2017). Bilişsel kalıpların da şekillenmesine etki eden çocukluk dönemi yaşantıları yalnızca örseleyici yönüyle değil maruz kalınan sosyo-kültürel yapının da etkisiyle duygu düzenleme üzerinde etkin roldedir. Bireyde birtakım şemaların oluşması gelişim süreçleri boyunca dışardan edinilen bilgiler sayesinde gerçekleşir. Günlük aktivite ve davranışlarında otomatik davranış ve düşünce örüntüleri geliştiren insanlar belirli bir süreden sonra bu gelişimi azaltırlar (Yıldız, 2017). Birtakım otomatik düşüncelerin negatif, özellikle de depresif yönde olması hem çocukluk örselenmeleri ile olan ilişkisi açısından hem de duygulanım ve düzenlenmesine olan etkisinden dolayı son derece önemlidir.

$\mathrm{Bu}$ araştırmada, bahsi geçen özelliklerinden dolayı duygu düzenlemeyi etkileyen unsurlardan özellikle çocukluk örselenmeleri ve otomatik düşünceler üzerinde durulmuştur. Bilişlerin belirginleştiği dönem olan çocukluk döneminde maruz kalınan davranışlar duygular üzerinde ne kadar etkili ise bu davranışların ve diğer yaşamsal olayların etkisiyle meydana gelen otomatik düşünceler de o kadar etkilidir. Bu unsurların ortaya çıkardığg engeller ya da yardımlar vasıtasıyla da bilişsel duygu düzenleme becerilerini kullanma kapasitesi ortaya çıkmaktadır (Meyer, 2008). İnsandan insana duygusal tepkiler birtakım farklılıklar gösterse de bütün insanlar sahip oldukları duyguları düzenlemek için birtakım stratejiler kullanmaktadır. Farklı yaşam tarzlarına rağmen temelde benzer stratejilerin kullanılmasının sebebi benzer çocukluk 
dönemleridir. Piaget, ortaya koyduğu bilişsel gelişim kuramında insanın bilişsel gelişimine ilişkin en somut açıklamayı ortaya koymuştur. Gelişimin hamilelikten itibaren başladığını belirttiği kuramında Piaget, bilişsel gelişimin insanın çevreye adaptasyon çabalarının bir ürünü olduğu iddia etmiştir (Piaget, 1964, akt. Karmiloff-Smith, 1995). Şemaların oluşturulmaya başlandığı çocukluk döneminde edinilen örseleyici tecrübelerin etkisi oldukça fazladır. Çocukluk dönemi örselenmeleri, çocuğun yaşam alanı içerisinde herhangi bir sebebe dayanmaksızın gerçekleşebilir (Young, Klosko \& Weishaar, 2003).

Çocuğun fiziksel ve psikolojik gelişimini olumsuz etkileyebilecek davranışların tamamı olarak kabul edilen örseleyici davranışlara insanlık tarihi boyunca her dönemde ve her millette rastlanmıştır (Akduman, Akduman, Korkusuz ve Ruban, 2005). Fiziksel, duygusal ve cinsel olarak örseleyici yaşantıya maruz bırakılan çocukların tespit edilmesi toplumsal yapılardan dolayı zorlaşmaktadır. Özellikle Türkiye gibi sosyo-kültürel açıdan hem tutucu hem modern unsurları içerisinde barındıran ülkelerde bu yaşantılar ya aile içerisinde çözülmekte ya da tespit edilemediği için yıllar boyu devam etmektedir (Pelendecioğlu ve Bulut, 2009). Engelleyici unsurlara rağmen dünya üzerinde çocuğun korunmasına yönelik çalışma ve araştırmalar devam etmektedir. Dünya Sağlık Örgütü, 1988'de yaptığı bir araştırmada dünya üzerinde 900.000'den fazla çocuğun örseleyici davranışlara maruz kaldığını ortaya koymuştur. $\mathrm{Bu}$ çocukların $\% 50$ 'sinin ihmale, \%25'inin fiziksel istismara, \%12'sinin cinsel istismara, \%6'sının da psikolojik istismara maruz kaldığına dair veriler elde edilmiştir. Dikkat çeken diğer bir detay ise mağdur çocukların \%25'inin aynı anda birden fazla örseleyici yaşantıya maruz bırakıldığıdır (World Health Organisation, 2002). Benzer şekilde Türkiye için yapılan araştırmada, uygulanan örseleyici davranışlar açısından ilk sırada duygusal istismar \%78 gibi bir oranla yer almaktadır. Fiziksel istismar \%24 ve cinsel istismarın \%9 olarak tespit edildikleri araştırmadan anlaşılacağı üzere bazı çocuklar birden farklı istismar davranışına maruz kalmaktadır. (Turhan, Sangün ve İnand1, 2006). Bir örseleyici istismar davranışının bile çocuk üzerindeki uzun süreli etkisi düşünüldüğünde, birden fazlasına maruz kalan bireyin yaşayacağı travmatik etki daha çok olabilmektedir.

Dünya Sağlık örgütü 2002 yılında yaptığı diğer bir tespitle ortaya koyduğu rakamlarla o y1l dünya genelinde yaklaşık 53.000 çocuğun öldürüldüğü bilgisini kamuoyuna sunmuştur. Aynı y1l 15 milyon kız, 73 milyon erkek çocuğun cinsel istismara maruz kaldığını belirtmiştir (World Health Organisation, 2002). Farklı yıllarda yapılan çalışmalarda görülen rakamlar dünya genelinde korkutucu boyutlarda görülürken bazı gelişmiş ve gelişmekte olan ülkeler için de durum farksızdır. NCA (National Children's Alliance) 2015 yılında yaptığı araştırmada, yalnızca Amerika'da 700.000 çocuğun istismar ve ihmal davranışına maruz kaldığını, bu çocuklardan 1670 tanesinin hayatını kaybettiğini ortaya koymuştur (Nolas, 2015). Türkiye, bu durumdan muzdarip ülkelerden birisidir. Adalet Bakanlığı'nın açıkladığg verilere göre 2014 yılında her ay Adli Tıp Kurumu'na ortalama 650 çocuk cinsel istismar vakası gönderilmiştir. Ayrıca, her 4 tecavüz davasından birisi çocuklarla ilgilidir. $\mathrm{Bu}$ ve benzeri rakamların ortaya koyulduğu çalışmalar farklı toplumlarda örselenmiş bireylerin yetişerek topluma karıştı̆̆ını gözler önüne sermektedir (Münevver, Kızıltepe ve Kandır, 2014). Ayrıca, Türkiye İstatistik Kurumu ortaya koyduğu verilerde Türkiye'de cinsel istismar oranlarının her geçen gün arttığını ortaya koymuştur. TÜIKK verilerine göre, 2014 yılında tespit edilen istismara uğrayan çocuk sayıs 74 bin 64 iken bu rakam 2016 yılında 83 bin 552'ye ulaşarak kısa bir süre için oldukça yüksek bir artış1 gözler önüne sermiştir. Adli Sicil ve İstatistik Genel Müdürlüğü de diğer 
analizlere benzer şekilde sonuca varmış ve açıklamasında 2006 yılında \% 42,5 oranındaki cinsel istismara ilişkin hükümlülük oranının 2016 yılında \%58'e çıktığını belirtmiştir (Kılıç, 2016).

Çocukluk ve ergenlik döneminde riskli durumların içerisinde kalan bireyler sonraki gelişim görevlerini tamamlama konusunda sıkıntılar yaşamaktadır. Gelişimsel kriz dönemi olarak da adlandırılan ergenlik döneminin sosyal ve duygusal çalkantılarıyla karşı karşıya kalan bireylerin zihinsel gelişimleri de aynı şekilde sekteye uğramaktadır (Conger \& Conger, 2002). Duyguları ifade etme biçimlerini öğrenmeyi güçleştiren örseleyici yaşantılar, aynı zamanda belirli düşünce biçimlerine bağlanmaya da sebep olur. Diğer bir deyişle, sabitleşmiş inanç ve şemalar insanın hayatına yön verir. Otomatik düşünceler, insanın kendi iradesi ile düşünce geliştirmesine engel olmakta, ayrıca belirli ideoloji, din, kültür, tutum vb. etmenlerine bağlı olarak insanın özgürce duygulanım hakkına ket vurmaktadır. Bilişlerde kendine özgü bozulmalara sebep olmasından dolayı otomatik düşünceler insanın duygu dünyasıyla da ayrıca ilişkilidir. Otomatik düşüncelerin, duyguya, çevreye, kişiye ve olaya göre duygulanımda etkisini gösterdiği zaman gerek depresif yapılı düşünceye, gerek kişiyi yanlış açılardan bakmaya yönlendirmesi ile bu ilişkiyi açıkça ortaya koymaktadır (Beck, 2001).

İnsanların eğitim hayatlarına başladıkları erken yaşlardan itibaren karşılaşmaları muhtemel bazı yaşantılar vardır. $\mathrm{Bu}$ yaşantılar zaman zaman birbirleriyle etkileşim halinde bulunurlar. Bu araştırmanın ana unsurlarından olan bilişsel duygu düzenleme stratejilerini kullanma becerisi, diğer bir ana unsuru olan çocukluk örselenme yaşantılarının türüne göre olumsuz etkilenebilir. Bu bağlamda duygu düzenleme becerilerinin stres ve travma yaratan yaşantılardan sonra daha negatif yönde ilerlediğini gösteren düşünceler alanyazında mevcuttur (Garnefski, Kraaij \& Van Etten, 2005; Min, Yu, Lee \& Chae, 2013). Fiziksel, psikolojik ve cinsel anlamda örseleyici istismar davranışları birey üzerinde bilişsel bozulmalara yol açacağı gibi, farklı açılardan sosyal yaşantıyı da sekteye uğratacaktır. İnsanlarda gelişebilecek benliğe ilişkin bozulmaların başında stres verici olaylardan dolayı kendini suçlama davranışı gelir (Anderson, Miller, Riger, Dill \& Sedikides, 1994). Bu yanlış çıkarımın önemi birçok farklı çarpık düşünceye sebep olabilecek potansiyelde olmasıdır. Örneğin, kişi kendini suçlama davranışından dolayı tekrar odaklanmayı gerçekleştiremez ya da durumun düzeleceğine ilişkin olumlu düşünce geliştiremez (Garnefski vd., 2001). Görüldüğüü üzere çocukluk örselenmeleri ve otomatik düşüncelerin bilişsel duygu düzenleme kapasitesi üzerinde belirgin bir etkisi bulunduğu düşünülmektedir.

Toplum içerisinde kendine yer bulmuş, farklı kültür, din, karakter vb. tercihlere sahip gruplar yer almaktadır. Eğitim öğretim kademelerinde kendilerine değer katmaya devam eden bireylerin geliştirdikleri karakterin yapı taşlarını oluşturan unsurlar bu farklılıklardan meydana gelmektedir (Garnefski, Kraaij \& Spinhoven, 2001; Thompson, 1991). Üniversite eğitim kademesine gelmiş, eğitimini tamamladığı zaman toplum içerisine karışarak toplumsal yapıya karşı görev ve sorumluluklarını yerine getirmek üzere yaşamlarını sürdürecek olan genç zihinlerin duygu düzenleme kapasiteleri sağlam temelli nesiller yetiştirmek için son derece önemlidir. $\mathrm{Bu}$ araştırmanın amacı, üniversite öğrencilerinin bilişsel duygu düzenlemelerinde çocukluk örselenmeleri ve otomatik düşüncelerin yordayıcı rolünü incelemektir. Araştırmanın amacına bağlı olarak, araştırmada bağımsız değişken vazifesi gören çocukluk örselenmelerinin ve otomatik düşüncelerinin bilişsel duygu düzenlemenin anlamlı birer yordayıcıları olma durumuna cevap aranmıştır. 


\section{Yöntem}

$\mathrm{Bu}$ çalışma üniversite öğrencilerinin bilişsel duygu düzenlemelerinin çocukluk örselenmeleri ve otomatik düşünceleri ile olan ilişkisini ortaya koymayı amaçladığından betimsel niteliktedir. $\mathrm{Bu}$ betimsel çalışmanın tasarlanması aşamasında desen olarak ilişkisel tarama modeli seçilmiştir.

\section{Çalışma Grubu}

Araştırma grubunu 2017-2018 eğitim öğretim yılında Zonguldak Bülent Ecevit Üniversitesi’nde eğitim görmekte olan 652 lisans öğrencisi oluşturmaktadır. Araştırma için basit seçkisiz örnekleme yöntemi kullanılmıştır. Üniversite birinci sınıf öğrencilerinin henüz uyum sürecinde oldukları ve dördüncü sınıf öğrencilerinin mezuniyet sürecinde oldukları varsayımlarına dayanarak çalışma grubu yalnızca ikinci ve üçüncü sınıflardan oluşturulmuştur. Çalışma grubunun rastgele ve gönüllülük esasına uygun olarak seçilmesi için öncelikle fakülteler arasında kura çekimi yapılmıştır. Kura sonucunda seçilen Ereğli Eğitim Fakültesi, Denizcilik Fakültesi, İktisadi ve İdari Bilimler Fakültesi ve Fen- Edebiyat Fakültesi öğrencileriyle yüz yüze iletişime geçilmiş, gönüllü olan öğrencilere ölçekler uygulanmıştır. Uygulama her fakültede sınıf ortamında gruplar halinde olarak gerçekleştirilmiştir. Araştırma grubunun demografik özellikleri Tablo 1'de verilmiştir.

\section{Tablo 1. Katılımcı Demografik Özellikleri}

Değişken $\quad$ Frekans $\quad$ Yüzde (\%)

(f)

\begin{tabular}{lll}
\hline Cinsiyet & & \\
\hline Kadın & 423 & 64.9 \\
Erkek & 229 & 35.1 \\
Toplam: & 652 & \\
\hline Yaş & & \\
\hline 19 & 111 & 17 \\
20 & 185 & 28.4 \\
21 & 168 & 25.8 \\
22 & 97 & 14.9 \\
23 & 41 & 6.3 \\
24 & 22 & 3.4 \\
$25+$ & 8 & 4.4 \\
Toplam & 652 & 100 \\
\hline
\end{tabular}




\section{Çalışmada Kullanılan Ölçme Araçları}

\section{Bilişsel Duygu Düzenleme Ölçeği:}

Garnefski vd. (2002), bilişsel duygu düzenleme ölçeğini insanların kaygı hali yaratacak tecrübelerin sonrasında ya da normal yaşantılarında duygularını düzenlemek için kullandıkları duygu düzenleme stratejilerini saptamak amacıyla geliştirmiştir. Ölçek beşli likert tipindedir. Otuz altı maddeden oluşan bilişsel duygu düzenleme ölçeği, uyumlu ve uyumsuz bilişsel başa çıkma stratejilerini barındıran 9 alt boyuttan oluşmaktadır. Ölçeği meydana getiren alt boyutlar, uyumlu başa çıkma stratejileri olan; kabul, plan yapmaya tekrar odaklanma, pozitif tekrar odaklanma, pozitif yeniden gözden geçirme, bakış açısına yerleştirme ve uyumsuz başa çıkma stratejileri olan kendini suçlama, ruminasyon, felaketleştirme ve diğerlerini suçlamadır. Yapılan güvenirlik çalışmasına göre ölçeğin Cronbach Alpha değerinin 0.68 ile 0.83 arasında değişkenlik gösterdiği belirlenmiştir (Garnefski vd., 2002). Ölçek Onat ve Otrar (2010) tarafından Türkçe'ye uyarlanmıştır. Uyarlanma çalışmaları üniversite öğrencileri ile gerçekleştirilmiştir. Araştırmacıların yaptığ çalışmalar neticesinde iç tutarlılık katsayısı 0.78 ve test tekrar teste göre güvenirlik katsayısı ise " $r=0.10$ " olarak hesaplanmıştır. Yapılan geçerlik analizlerine de bakılarak ölçeğin madde ayırt ediciliği yüksek, güvenilir ve geçerli bir ölçüm aracı olduğu kararına varılmıştır (Onat ve Otrar, 2010). Bilişsel Duygu Düzenleme Ölçeği'nin bu çalışmada cronbach alfa güvenirlik katsayısı $\alpha=0.784$ olarak hesaplanmıştır.

\section{Çocukluk Örselenme Yaşantıları Ölçeği Kısa Formu:}

Bernstein ve arkadaşları (2004) tarafından geliştirilmiş olan Çocukluk Dönemi Örselenme Yaşantıları Ölçeği Kısa Formu, çocuklukta yaşanılan istismar geçmişini incelemede kullanılan geriye yönelik bir ölçektir. Kaya (2014), bu ölçeğin Türkçe’ye uyarlanması çalışmalarını yapmıştır. Uyarlanma çalışmaları üniversite öğrencileri ile gerçekleştirilmiştir. Ölçeğin hem orijinali hem de uyarlanmış hali 28 maddeden oluşmaktadır. ÇÖYÖ-KF 5'li likert tipinde bir ölçme aracıdır. Ölçek beş alt boyuttan oluşmaktadır. Bunlar; fiziksel istismar, cinsel istismar, duygusal istismar, fiziksel ihmal ve duygusal ihmal alt boyutlarıdır. Türkçe'ye uyarlanmış olan formda yapılan güvenirlik çalışmaları sonucunda iç tutarlılık katsayısı 0.77 olarak hesaplanmıştır. Kaya (2014), kısa formun orijinal ölçekle benzerliğini ölçmek amacıyla faktör analizi gerçekleştirmiştir. Elde edilen bulgulara göre ölçeğin orijinal ölçekle hem bütün olarak hem de alt boyutlar olarak uyum gösterdiği tespit edilmiştir. Sonuç olarak Türkçe'ye uyarlanmış Çocukluk Örselenmeleri Ölçeği Kısa Formu, belirlenen yaş kademeleri arasındaki kişilere uygulanabilecek seviyede güvenilir ve geçerli kabul edilmiştir. Bu çalışmadan elde edilen bulgular doğrultusunda yapılan güvenirlik analizinde Çocukluk Örselenme Yaşantıları Ölçeği Kısa Formu cronbach alfa katsayısı 0.67 olarak hesaplanmıştır.

\section{Otomatik Düşünceler Ölçeği:}

Hollon ve Kendall (1980) tarafindan geliştirilen bu ölçek insanların depresyon eğilimi edinmelerine yol açabilecek olumsuz otomatik düşüncelerin akıllarından ne sıklıkla geçtiğini saptamak için kullanılmaktadır. Ölçeğin tek alt boyutu depresyondur. Ölçek 30 maddeden oluşur ve 5'li likert tipindedir. Ölçeğin Türkçe’ye uyarlama çalışmalarını yapan Aydın ve Aydın (1990), gerçekleştirdikleri güvenirlik analizi sonucunda cronbach alpha katsayısını 0.95 olarak hesaplamışlardır. Ölçeğin test tekrar test güvenirliği ise 30 kişilik bir öğrenci grubuyla yapılan uygulama sonucunda $r=0.77$ değeri bulunmuştur. (Aydın ve Aydın, 1990). Elde edilen bulgular 
Türkçe' ye uyarlanan bu ölçeğin bilimsel çalışmalarda kullanılmaya uygun olduğunu kanıtlamaktadır. Otomatik Düşünceler Ölçeği'nin bu çalışmada cronbach alfa katsayısı 0.95 olarak bulunmuştur.

\section{İşlem}

İstatistiksel işlemlere geçilmeden önce verilerin normal dağılıp dağılmadığını tespit etmek amacıyla normallik testi yapılmıştır. Elde edilen çarpıklık ve basıklık değerlerine göre, her üç ölçeğin puanlarının normal dağılım kritik noktaları olan -3 ile +3 arasında olduğu tespit edilmiş ve normallik varsayımı sağlanmıştır (Gravetter, F. J. \& Wallnau, 2016). Regresyon analizi için gerekli diğer bir varsayım olan varyansların eşitliği test edilmiş ve elde edilen değer kritik değer olan 0.05 in üstünde bulunmuş ve varsayım sağlanmıştır. Araştırmanın değişkenleri arasındaki ilişki Pearson Korelasyon katsayısı ile incelenmiş ve arkasından çocukluk örselenmeleri ve otomatik düşüncelerin bilişsel duygu düzenlemeyi yordama gücünü belirlemek için standart çoklu regresyon analizi yapılmıştır. Araştırmada, manidarlık düzeyi 0.05 olarak kabul edilmiştir. Güncel çalışmalarda kullanılmakta olan ve Türkçe'ye uyarlama çalışmalarının güncel bir tarihte yapılmış olmasından dolayı Bilişsel Duygu Düzenleme Ölçeği ve Çocukluk Örselenme Otomatik Düşünceler Ölçeği Kısa Formu için faktör analizine ihtiyaç duyulmamıştır. Diğer yandan Otomatik Düşünceler Ölçeği Türkçe'ye uyarlama çalışmaları daha eski tarihte olduğundan dolayı faktör yapısı açısından incelenmiş ve yapılan faktör analizi ölçeğin tek alt boyutu olan depresyonu niteler şekilde bir faktörde toplandığını ortaya koymuştur. Sonuç olarak, araştırmada kullanılan üç ölçek kullanılmak üzere yeterli güvenirlik geçerlilik değerlerine sahiptir.

\section{Bulgular}

Çocukluk örselenmelerin, fiziksel istismarın, duygusal istismarın, cinsel istismarın, fiziksel ihmalin, duygusal ihmalin ve otomatik düşüncelerin bilişsel duygu düzenlemenin yordayıcıs1 olup olmadığını tespit etmek için çoklu standart regresyon analizi öncesi yapılan, değişkenler arası ikili ilişkileri gösteren korelasyon katsayıları ve betimsel istatistik sonuçları Tablo 2'de gösterilmiştir. 
Tablo 2. Değișkenler Arasındaki Korelasyon Katsayıları ve Değișkenlere İlișkin Betimsel İstatistikler

\begin{tabular}{llllllllll}
\hline Değişkenler & 1 & 2 & 3 & 4 & 5 & 6 & 7 & 8 & 9 \\
\hline 1.Uyumlu BDD & & & & & & & & &
\end{tabular}

2.Uyumsuz BDD

$$
, 24 * *
$$

3.Fiz. İstismar

$$
-, 04 \quad, 09 *
$$

4.Cins. İstismar

$$
-, 03 \quad, 02 \quad, 40^{* *}
$$

5.Duy.İstismar

$$
-, 03 \quad, 19 * * \quad, 55 * * \quad, 33^{* *}
$$

6.Fiz. İhmal

$$
-, 09 * \quad, 14 * * \quad, 38 * * \quad, 28 * * \quad, 38 * *
$$

7.Duy. İhmal

$$
-, 17 * * \quad, 11 * * \quad, 38^{* *} \quad, 21 * * \quad, 47 * * \quad, 512 * *
$$

8. COYO Toplam

9. Ot. Düşünceler

$$
-, 07 \quad, 14 * * \quad, 73 * * \quad, 63 * * \quad, 72 * * \quad, 242 * * \quad, 63^{* *}
$$

** $\mathrm{p}<0,01{ }^{*} \mathrm{p}<0,05$

$-, 13 * * \quad, 45 * * \quad, 17 * * \quad, 05 * * \quad, 24 * * \quad, 675^{* *} \quad, 28 * * \quad, 25 * *$

Tablo 2 incelendiğinde, uyumlu bilişsel duygu düzenleme ile fiziksel istismar arasında $-0,04$, cinsel istismar arasında $-0,03$, duygusal istismar arasında $-0,03$, fiziksel ihmal arasında 0,09 , duygusal ihmal arasında $-0,17$, çocukluk örselenmeleri arasında $-0,07$ ve otomatik düşünceler arasında $-0,13$ düzeyinde ilişki bulunmuştur. Ayrıca, uyumsuz bilişsel duygu düzenleme ile fiziksel istismar arasında 0,09, cinsel istismar arasında 0,02, duygusal istismar arasında 0,19 , fiziksel ihmal arasında 0,14 , duygusal ihmal arasında 0,11 , çocukluk örselenmeleri arasında 0,14 ve otomatik düşünceler arasında 0,45 düzeyinde ilişki bulunmuştur. Özetle bağımsız değişkenlerin birbiriyle ve bağımlı değişkenlerle 0,005 ve 0,452 arasında korelasyona sahip olduğu görülmektedir. Korelasyon değerleri çoklu bağlantı riski açısından, 0,90’1 geçmemektedir (Çokluk, Şekercioğlu ve Büyüköztürk, 2014). Bu nedenle çoklu bağlantı problemi olmadığından regresyon analizine devam edilmiştir. Çocukluk örselenme yaşantılarının ve otomatik düşüncelerin uyumlu bilişsel duygu düzenlemeyi yordayıp yordamadığını belirlemek için yapılan standart çoklu regresyon analiz sonuçları Tablo 3'te ve çocukluk örselenme yaşantılarının uyumlu bilişsel duygu düzenlemeyi yordayıp yordamadığını belirlemek için yapılan standart çoklu regresyon analiz sonuçları Tablo 4'te sunulmuştur. 
Tablo 3. Çocukluk Örselenme Yaşantılarının ve Otomatik Düşüncelerin Uyumlu Bilişsel Duygu Düzenlemeyi Yordamasına İlişkin Çoklu Regresyon Analizi

\begin{tabular}{llllllll}
\hline Değişken & B & Standart Hata B & $\beta$ & T & p & $\begin{array}{l}\text { İkili } \\
\text { R }\end{array}$ & $\begin{array}{l}\text { Kısmi } \\
\mathrm{R}\end{array}$ \\
& & & & & & & \\
\hline Otomatik Düşünceler &,- 177 &, 052 &,- 134 & $-3,439$ &, 001 &,- 134 &,- 134 \\
Çocukluk Örselenmeleri &, 125 &, 065 &,- 075 & 1,918 &, 056 &, 075 &, 075 \\
\hline $\mathrm{R}=, 210 \quad \mathrm{R}^{2}=, 044$ & & & & & & & \\
$\mathrm{~F}_{(7,644)}=4,260 \quad \mathrm{p}=, 000$ & & & & & & &
\end{tabular}

Tablo 3'e göre tüm bağımsız değişkenler uyumlu bilişsel duygu düzenlemenin toplam varyansının \%4'ünü $\left(\mathrm{R}=, 210, \mathrm{R}^{2}=, 044, \mathrm{~F}(7-644)=4,260 \mathrm{p}<, 01\right)$ oluşturmaktadır. Regresyon katsayılarının anlamlılı̆̆ına ilişkin analiz sonuçları otomatik düşüncelerin $(\mathrm{t}=-3,439, \mathrm{p}<, 05)$ uyumlu bilişsel duygu düzenlemeyi anlamlı olarak yordadığ 1 ve çocukluk örselenmelerinin ( $\mathrm{t}=$ 1,918), uyumlu bilişsel duygu düzenlemeyi anlamlı olarak yordamadığı tespit edilmiştir.

Tablo.4 Çocukluk Örselenme Yaşantılarının Alt Boyutlarının Uyumlu Bilişsel Duygu Düzenlemeyi Yordamasına İlişkin Çoklu Regresyon Analizi

\begin{tabular}{llllllll}
\hline Değişken & B & Standart Hata в & $\beta$ & $\mathrm{T}$ & $\mathrm{p}$ & $\begin{array}{l}\text { İkili } \\
\mathrm{R}\end{array}$ & $\begin{array}{l}\text { Kısmi } \\
\mathrm{R}\end{array}$ \\
& & & & & & & \\
\hline Cinsel İstismar &,- 056 &, 061 &,- 055 &,- 909 &, 364 &,- 028 &,- 036 \\
Duygusal İstismar &, 057 &, 044 &, 065 & 1,299 &, 195 &,- 030 &, 051 \\
Fiziksel İstismar &, 008 &, 058 &, 006 &, 130 &, 896 &,- 040 &, 005 \\
Fiziksel İhmal &,- 008 &, 040 &,- 010 &,- 211 &, 833 &,- 094 &,- 008 \\
Duygusal İhmal &,- 166 &, 043 &,- 194 & $-3,905$ &, 000 &,- 169 &,- 152 \\
\hline
\end{tabular}

$\mathrm{R}=, 210 \quad \mathrm{R}^{2}=, 044$

$\mathrm{F}_{(7,644)}=4,260 \mathrm{p}=, 000$

Regresyon katsayılarının anlamlılığına ilişkin analiz sonuçları duygusal ihmalin ( $\mathrm{t}=$ $3,95, \mathrm{p}<, 05)$ uyumlu bilişsel duygu düzenlemeyi negatif yönde anlamlı olarak yordadığını göstermektedir. Ayrıca, cinsel istismar $(\mathrm{t}=-, 909)$, duygusal istismarın $(\mathrm{t}=1,299)$, fiziksel istismarın $(t=, 130)$ ve fiziksel ihmalin $(t=, 211)$ uyumlu bilişsel duygu düzenlemeyi anlamlı olarak yordamadığı tespit edilmiştir. Standardize edilmiş regresyon katsayılarına göre, uyumlu bilişsel duygu düzenlemenin anlamlı yordayıcıları önem sırasına göre duygusal ihmal $(\beta=-, 194)$ ve otomatik düşünceler $(\beta=-, 134)$ 'dir. Çocukluk örselenme yaşantılarının ve otomatik düşüncelerin uyumsuz bilişsel duygu düzenlemeyi yordayıp yordamadığını belirlemek için yapılan standart çoklu regresyon analiz sonuçları Tablo 4'te ve Çocukluk örselenme yaşantılarının uyumsuz bilişsel duygu düzenlemeyi yordayıp yordamadığını belirlemek için yapılan standart çoklu regresyon analiz sonuçları Tablo 5'te ve sunulmuştur. 
Tablo 5. Çocukluk Örselenme Yaşantılarının ve Otomatik Düşüncelerin Uyumsuz Bilişsel Duygu Düzenlemeyi Yordamasına İlişkin Çoklu Regresyon Analizi

\begin{tabular}{llllllll}
\hline Değişken & B & Standart Hata в & $\beta$ & $\mathrm{t}$ & $\mathrm{p}$ & $\begin{array}{l}\text { Íkili } \\
\mathrm{R}\end{array}$ & $\begin{array}{l}\text { Kısmi } \\
\mathrm{R}\end{array}$ \\
\hline Çocukluk Örselenmeleri &, 244 &, 069 &, 137 & 3,524 &, 000 &, 137 &, 137 \\
Otomatik Düşünceler &, 592 &, 047 &, 447 & 12,717 &, 000 &, 447 &, 447 \\
& & & & & & & \\
\hline $\begin{array}{l}\mathrm{R}=, 456 \quad \mathrm{R}^{2}=, 208 \\
\mathrm{~F}_{(7,644)}=24,166 \mathrm{p}=, 000\end{array}$ & & & & & & & \\
\end{tabular}

Tablo 5'e göre, tüm bağımsız değişkenler uyumsuz bilişsel duygu düzenlemenin toplam varyansının \%20'sini ( $\mathrm{R}=, 456, \mathrm{R} 2=, 208, \mathrm{~F}(7-644)=24,166 \mathrm{p}<, 01)$ oluşturmaktadır. Regresyon katsayılarının anlamlılığına ilişkin analiz sonuçları çocukluk örselenmelerinin $(t=3,524, p<, 05)$, ve otomatik düşüncelerin $(t=12,717, p<, 05)$ uyumsuz bilişsel duygu düzenlemeyi pozitif yönde anlamlı olarak yordadığını göstermektedir.

Tablo 6. Çocukluk Örselenme Yaşantılarının Alt Boyutlarının Uyumsuz Bilişsel Duygu Düzenlemeyi Yordamasına İlişskin Çoklu Regresyon Analizi

\begin{tabular}{|c|c|c|c|c|c|c|c|}
\hline Değişken & B & Standart Hata в & $\beta$ & $\mathrm{t}$ & $\mathrm{p}$ & $\begin{array}{l}\text { İkili } \\
\mathrm{R}\end{array}$ & $\begin{array}{l}\text { Kısmi } \\
\text { R }\end{array}$ \\
\hline Cinsel İstismar &,- 070 & ,047 &,- 064 & $-1,510$ & ,131 & ,016 &,- 059 \\
\hline Duygusal İstismar & , 188 & ,047 & 199 & 4,032 &, 000 & 193 & 157 \\
\hline Fiziksel İstismar &,- 032 & ,062 &,- 025 &,- 514 & 608 & ,090 &,- 020 \\
\hline Fiziksel İhmal &,- 094 & ,042 & 107 & 2,226 & ,026 & 141 & ,087 \\
\hline Duygusal İhmal &,- 022 & ,045 &,- 024 &,- 481 & 631 & , 106 &,- 019 \\
\hline
\end{tabular}

Regresyon katsayılarının anlamlılığına ilişkin analiz sonuçları duygusal istismarın ( $\mathrm{t}=$ 4,032, $\mathrm{p}<, 05)$, ve fiziksel ihmalin ( $\mathrm{t}=2,226, \mathrm{p}<, 05)$ uyumsuz bilişsel duygu düzenlemeyi pozitif yönde anlamlı olarak yordadığını göstermektedir. Ayrıca, cinsel istismarın $(t=-1,150)$ ve fiziksel istismarın $(\mathrm{t}=-, 514)$ duygusal ihmalin $(\mathrm{t}=-, 481)$ uyumlu bilişsel duygu düzenlemeyi anlamlı olarak yordamadığı tespit edilmiştir. Standardize edilmiş regresyon katsayılarına göre, uyumsuz bilişsel duygu düzenlemenin anlamlı yordayıcıları önem sırasına göre otomatik düşünceler $(\beta=12,717)$, fiziksel ihmal $(\beta=2,226)$, duygusal istismar $(\beta=-, 199)$ ve çocukluk örselenmeleri $(\beta=, 137)$ 'dir.

\section{Tartışma ve Sonuç}

Araştırmanın alt problemlerinde yer alan değişkenlerin birbirleriyle ilişkisini ele alan alanyazın incelendiğinde, doğrudan bilişsel duygu düzenleme, çocukluk örselenmeleri ve otomatik düşünceleri ele alan birçok çalışmaya rastlanmıştır. Bilişsel duygu düzenleme, çocukluk 
örselenme yaşantıları ve otomatik düşüncelerle benzerlik gösteren farklı değişkenleri ele alan çalışmalar da incelenmiş, sonuçlarında paralellik tespit edilmiştir. Araştırma problemlerine yönelik elde edilen sonuçlar bu araştırmalardan destek alınarak tartışılmıştır. Bu çerçevede, uyumlu ve uyumsuz stratejilerin üzerinde çocukluk örselenme yaşantıları ve otomatik düşüncelerin yordayıcı rolü incelenmiştir.

$\mathrm{Bu}$ çalışmada, çocukluk örselenme yaşantılarının uyumlu bilişsel duygu düzenlemenin anlamlı bir yordayıcısı olmadı $\breve{g} 1$ ve uyumsuz bilişsel duygu düzenlemenin anlamlı bir yordayıcı olduğu tespit edilmiştir. Alanyazın incelendiğinde bu ilişkiyi doğrudan ve dolaylı olarak doğrulayan çalışmalar tespit edilmiştir. Kaya ve Çeçen Eroğul (2016), araştırmasından elde ettiği bulgulara dayanarak çocukluk örselenmeleri ile uyumlu duygusal davranış arasında düşük seviyede ilişki olduğunu ortaya koymuştur. Benzer şekilde, Bilim (2012) çocukluk istismar yaşantısı ile duygu düzenleme güçlüğü arasındaki ilişkiyi incelemek üzere yaptığı çalışmada, çocukluk istismar yaşantısı ile bilişsel duygu düzenleme güçlüğü arasında negatif korelasyon olduğu sonucuna varmıştır. Huh, Kim, Lee ve Chae (2017) bilişsel duygu düzenleme ile çocukluk dönemi travmaları arasındaki ilişkiyi inceledikleri çalışmalarında, uyumsuz bilişsel duygu düzenleme stratejileri ile çocukluk istismar yaşantıları arasında anlamlı bir ilişki olduğunu tespit etmişlerdir. Her iki çalışma sonuçlarından anlaşılacağı üzere, çocuklukta karşılaşılan örseleyici davranışlar kişide uyumsuz duygu düzenleme stratejilerinin gelişmesine sebep olmaktadir.

Ergenlik ve ergenlik öncesi dönemde maruz kalınan örseleyici davranışın bireyde duygu düzenleme anlamında yön belirleyici etkisi olduğu anlaşılmıştır. İstismarcı ve ihmalci davranışa maruz kalan bireyler uyumsuz bir duygu düzenleme yolu izlerken, bunlara alt düzeyde maruz kalan veya hiç kalmayan bireyler daha uyumlu bir yol izlemektedir. Hangi tür örseleyici davranış olursa olsun kişide bilişsel bir etki bıraktığ 1 göz önüne alınacak olursa, bu tarz bir ilişkinin ortaya çıkması muhtemeldir. İnsanların bilişsel yapılarına etki eden istismarcı ve ihmalci davranışlar, bilişsel şemaların gelişim dönemlerinde ilerleyeceği yolu belirlemektedir (Demirkap1, 2014). Buna örnek olarak, istismara maruz kalan bir bireyin özellikle 11-17 yaş aralığında bilişsel ve duygusal olarak kendini suçlaması gösterilebilir. Kişi, davranışı uygulayanı ve kendini suçlar ya da affeder ki bu da kişide aşağılık duygusu yaratarak bilişsel bir zedelenme oluşturur. Dolayısıyla kendisine ve çevresine güvenmemeye başlar. Yıllar boyunca insan ilişkilerinde çekingen davranış sergileyen bireyin sosyal gelişiminin aksaması bağlanma, etkileşim vb. yönlerden gelişimine de etki eder (Peleikis, Mykletun \& Dahl, 2005). Üniversite eğitimine geldikleri yaş itibariyle genel gelişiminde belirli seviyede yol alan bireyler ne seviyede örseleyici davranışa maruz kaldığına göre genel bir duygu düzenleme biçimi oluşturmuş olurlar. Türkiye'nin sosyokültürel yapısı insanların maruz kaldıkları örseleyici davranışları dile getirmesini kısıtlayıcı niteliktedir (Cüceloğlu, 2015). İnsanların kendilerini toplum içerisinde ifade edebilme becerisini kazanabileceği, çok kültürlü bir yapı olarak üniversite ortamı sosyokültürel yapının esnemesine olanak sağladığından dolayı fırsat niteliğinde olabilir. Elde edilen sonuçtan çıkarılacak önemli nokta çocukluk örselenmelerinin insanlarda uyumlu bilişsel duygu düzenleme becerileri gelişiminde belirleyiciliğinin olmadığıdır. Farklı niteliklerdeki örseleyici davranışlara yönelik alınacak toplumsal ya da aile içerisindeki tedbirlerin odak noktası insanların uyumsuz bilişsel duygu düzenlemelerinin önüne geçmek ve toplumsal düzene bu şekilde katkıda bulunmaktır. Uyumlu duygu düzenleme 
stratejileri kullanan bireylerin toplumda çoğunluk hale gelmesi ile toplumsal gelişim sağlanacağından dolayı çocukla iletişim konusunda toplumun bilinçlendirilmesi gerekmektedir.

$\mathrm{Bu}$ çalışmada, fiziksel istismar alt boyutunun uyumlu ve uyumsuz bilişsel duygu düzenleme üzerinde anlamlı bir yordayıcılığı olmadığı tespit edilmiştir. Fiziksel istismara maruz kalan çocukların farklı açılardan gelişimsel gerilemeler yaşadığını ve duygusal yapılarında birtakım zedelenmeler olduğunu ortaya koyan çalışmalar bulunmaktadır (Taner ve Gökler, 2004). Demirkapı (2014), ortaya koyduğu çalışmasında fiziksel istismarın kişide sosyal ve duygusal anlamda zedelenmelere yol açtığını belirtmiştir. Bu çalışmada, bilişsel duygu düzenleme üzerinde fiziksel istismar yaşantılarının herhangi bir etkisi olmaması sonucun ortaya çıkması farklı sebeplere dayandırılabilir. Türkiye'nin çok kültürlü yapısı içerisinde kültürden kültüre farklılık gösteren birçok unsur vardır. Farklılık göstermeyen unsurların başında ise geleneksel çocuk yetiştirme gelmektedir. Gelenekselci bakış açısı içerisinde yer alan "çocuğa fiziksel müdahalede bulunmanın doğal bir yaşam olayı olarak kabul edilmesi" ise araştırmada bu sonucun elde edilmesinin önemli bir etkeni olabilir. İnsanların fiziksel istismarı doğal bir davranış biçimi olarak kabul etmesi ve çocuğa bunu yansıtması çocukta bir nevi bunun kaçınılmaz bir olay olduğu algısını yaratır. Birey, öğrenilmiş çaresizlik içerisinde yıllar boyunca maruz kaldığı davranışı kabul eder ve negatif etkilerinin farkına varamaz (Şanlı ve Öztürk, 2012). Dolayısıyla, birey hem maruz kaldığı davranışın istismar olduğunun hem de fiziksel müdahale ile bastırılmış kişilik yapısının duygu kontrolünü olumsuz etkilediğinin bilincinde değildir. Güler, Uzun, Boztaş ve Aydoğan (2002), çekirdek aile yapısında ebeveynlerin çocuklarına fiziksel istismar gösterdiği vakalar saptamış, ancak çocuklarla yapılan analizlerde bunların tespitinin güçleştiğini belirlemiştir. Fiziksel istismarın uyumlu ve uyumsuz bilişsel duygu düzenlemeye herhangi bir etkisinin tespit edilmemesine yönelik geliştirilebilecek diğer bir bakış açısı ise istismarın duygusal anlamda zedeleyici seviyede olmamasıdır. Çalışmadan elde edilen bu sonuç, bahsi geçen gelenekselci çocuk yetiştirmede fiziksel istismarcı davranışların şiddetinin alt seviyede olmasının çocuklar üzerinde duygusal travma yaratmadığı görüşüyle yorumlanabilir.

$\mathrm{Bu}$ çalışmada, duygusal istismar alt boyutunun uyumlu bilişsel duygu düzenleme üzerinde anlamlı bir yordayıcı olmadığı, uyumsuz bilişsel duygu düzenleme üzerinde anlamlı bir yordayıcı olduğu tespit edilmiştir. Elde edilen sonuçtan anlaşılacağı üzere duygusal istismara maruz kalma düzeyi kişinin uyumsuz duygu düzenleme becerilerinde belirleyici bir rolde iken uyumlu duygu düzenleme düzeyinde anlamlı bir rolü bulunmamaktadır. İnsanların uyumlu yönde gelişim sağlaması için değil uyumsuz duygu düzenleme sergilemesini önleme açısından duygusal istismar yaşantılarının kontrolü önemlidir. Karagöz (2010) çocukluğunda duygusal istismara maruz kalan bireylerin kendini yaralama davranışı ve madde kullanımına eğilim gösterdiği ve duygu düzenleme güçlüğü çektiği görüşünü ortaya atmıştır. Güler, Uzun ve Boztaş (2002), çocukluk duygusal travmalarının bireyde uyumsuz duygu düzenlemeden kaynaklanan davranış bozukluklarına yol açtığını belirtmişlerdir. Bu araştırmacılar çalışmalarında, duygusal istismarın insanda çaresizlik, amaçsızlık, depresyon gibi duygulara sebep olmasından dolayı içsel ve çevreye yönelik duygu düzenleme kapasitesinin azaldığını savunmuşlardır. Erdoğan Yıldırım ve Tekinsav Sütçü (2016) madde ve alkol bağımlılarını katılımcı olarak kabul ettikleri çalışmalarında, erken dönem duygusal travma yaşantılarının bireyde duygu düzenleme güçlüğü yarattığını belirlemişlerdir. Koçyiğit, Sezer ve Yılmaz (2015) 60-72 aylık çocuklarda duygu düzenleme becerilerini konu edindiği çalışmalarında, ebeveynlerin çocuklarıyla kurdukları 
duygusal bağın gücünün çocuğun ilerleyen yaşlarında duygularını kontrol etmesine pozitif yönde etki ettiği görüşünü ortaya koymuşlardır. Bedirhanbeyoğlu (2018) çalışmasında, duygusal istismarın bilişsel duygu düzenleme stratejileri ile anlamlı ve anlamsız farklı ilişkilerini saptamıştır. Bedirhanbeyoğlu'nun elde ettiği bulgular arasından duygusal istismar ile uyumsuz bilişsel duygu düzenleme stratejileri arasında anlamlı bir ilişki bulması, bu araştırmada elde edilen bulguyla benzerlik göstermektedir.

Dolayısıyla, duygusal istismar ve benzeri yaşantıların çocukluktan yetişkinliğe kadar uyumsuz duygu düzenlemeye etkisini gösteren bulgular mevcuttur. Duygusal istismarın duygu düzenlemeye de etki etmesini açıklayan bir diğer faktör ise karakteristik ve yaşantısal farklılıklardır. Yeşilyaprak (1993) içinde bulunulan çevrenin karakter gelişimine olumlu ve olumsuz etkileri olduğunu dile getirdiği çalışmasında, etkinin olumlu veya olumsuz oluşunun genetik unsurlarla ilişkilendirilebileceğini öne sürmüştür. Buradan anlaşılacağı üzere, insanların uyumsuz stratejileri kullanmasında etken unsurlardan birisi de genetiktir. Kişi, karakter yapısına göre maruz kaldığı duygusal istismarı anlamlandırır ve hayatının kalanında duygularına yön verir. Farklı çalışmalardan elde edilen bulgulardan alınan destek, bu araştırmada duygusal istismarın uyumsuz duygu düzenleme stratejileri ile anlamlı ilişki içerisinde oluşunu destekler niteliktedir.

$\mathrm{Bu}$ çalışmada, cinsel istismar alt boyutunun uyumlu ve uyumsuz bilişsel duygu düzenleme üzerinde anlamlı bir yordayıcı olmadığı tespit edilmiştir. Ortaya çıkan bu sonuç alanyazında rastlanan bulgularla örtüşmemektedir. Bedirhanbeyoğlu (2018) cinsel istismar ile uyumlu bilişsel duygu düzenleme arasında anlamlı ve negatif yönde ilişki olduğunu tespit etmiştir. Bir diğer çalışmada, cinsel istismara maruz kalan bireylerin bilişsel bozulmalar ve duygusal problemler yaşadığı ve bunların uyumlu bilişsel duygu düzenleme stratejilerinin kullanımını engellediği öne sürülmüştür (Kendall Tackett \& Marshall, 1998). Bu çalışma, cinsel istismarın uyumlu bilişsel duygu düzenleme stratejileri ile anlamlı ve negatif yönde, uyumsuz bilişsel duygu düzenleme stratejileri ile anlamlı ve pozitif yönde bir ilişkisi olacağ beklentisiyle gerçekleştirilmiş ancak sonuçlar beklenildiği gibi çıkmamıştır. Cinsel istismarın ne derece büyük bir travmatik yaşantı olduğunu öne süren araştırmacılar bulunmaktadır (Tıraşçı ve Gören, 2007). Çalışmadaki bu sonuç farklı bakış açılarıyla değerlendirilebilir. Birinci bakış açısı, katılımcıların verdiği cevapların niteliğidir. Araştırma kapsamında üniversite öğrencilerine eğitim öğretim dönemi içerisinde toplu şekilde ölçek uygulaması yapılmıştır. Bu uygulama sınıf ortamında, öğrencilerin birbirlerinin cevaplarını görme ihtimali bulunan ders dinleme düzeninde yapılmıştır. Beş örseleyici yaşantı alt boyutu ile yapılan analizler sonucunda cinsel istismar puanlarının diğer iki istismar puanlarının toplamının 1/10'u oranında oluşu bu savı destekler niteliktedir. Diğer bakış açısı ise duyguların bastırılması ile alakalıdır. Cinsel istismar diğer türlere göre daha tehlikeli boyutlara ulaşabilir. Toplum baskısı, güven ortamı eksikliği, ekonomik yoksunluk, bilgisizlik, korku ve tehdit gibi etkenler ebeveyn ya da çocuğun bakımından sorumlu kişinin uyguladığı istismarın aile sınırları içerisinde kalmasına zemin oluşturur. Bu sayede, olaya dahil olan her bireyin toplumsal statüsüne herhangi bir zarar gelmesinin önüne geçilse de mağdur çocukta oluşan psikolojik travma dikkate alınmamaktadır. Dolayısıyla, mağdur çocuk bu travmanın üstesinden gelmek için kendine özgü savunma mekanizmaları geliştirmektedir. Psikolojik desteğin ilgili kişiler tarafından verilememesinden dolayı ortaya psikolojik rahatsızlıklar çıkmaktadır. Bu rahatsızlıklardan en yaygın olanı ise disosiyatif kişilik bozukluklarıdır. Cinsel istismar, birçok psikolojik rahatsızlığa yol açabileceği gibi bilişsel duygu düzenlemeleri de farklı yönlerden etkileyebilecek niteliktedir. Bu sebeple, 
cinsel istismarın bilişsel duygu düzenleme üzerindeki etkisi ile alakalı sonuca değil daha çok öğrencilerin verdiği cevapların niteliğine ilişkin tartışma ve yorum yapılmıştır.

Elde edilen bir diğer bulguya göre, fiziksel ihmal alt boyutunun uyumlu bilişsel duygu düzenleme üzerinde anlamlı bir yordayıcı olmadığı ve uyumsuz bilişsel duygu düzenleme üzerinde anlamlı bir yordayıcı olduğu tespit edilmiştir. Alanyazında, bu durumu destekleyen çalışmalar bulunmaktadır. Demirkapı (2014) çocukluk örselenmeleri, kimlik gelişimi ve duygu düzenleme arasındaki ilişkiyi incelediği çalışmasında, fiziksel ihmal davranışı ile uyumsuz duygu düzenleme arasında anlamlı ve pozitif yönlü bir ilişki olduğunu ortaya koymuştur. Bilim (2012) fiziksel ihmalin bilişsel duygu düzenleme üzerinde anlamlı etkisi olduğunu gösteren çalışma gerçekleştirmiştir. Özellikle fiziksel ihmalin tamamen dolaylı etkiden oluşması, bu davranışın bilişleri zedelediği takdirde duygu düzenleme kapasitesini etkileyeceği görüşüyle örtüşmektedir. Fiziksel ihmalin niteliği, miktarı ve uygulanış biçimi o davranışın ne düzeyde zarar vereceğini belirler. Bu kriterlerde ortaya çıkan dengesizliğe göre insan bilişleri zarar görür ve duygusal yapıya etki eder. Dolayısıyla, sosyal ilişkilerden edinilen duyguların kişiye ve çevreye yansımasında birtakım aksaklıklar meydana gelir (Soner ve Aykut, 2017). Bu gibi etkileri bilinen fiziksel ihmal yaşantılarının bilişsel duygu düzenleme üzerindeki etkisi alanyazındaki benzer çalışma sonuçlarıyla örtüşmesi açısından tatmin edici niteliktedir.

$\mathrm{Bu}$ çalışmada, duygusal ihmal alt boyutunun uyumlu bilişsel duygu düzenleme üzerinde anlamlı bir yordayıcı olduğu ve uyumsuz bilişsel duygu düzenleme üzerinde anlamlı bir yordayıcı olmadığı tespit edilmiştir. Duygusal ihmal alt boyutu elde edilen sonuçlar açısından en genel kavram olan çocukluk örselenmeleri içerisinde farkl1lık gösterir niteliktedir. Duygusal ihmalin niteliğine göre uyumlu bilişsel duygu düzenleme becerilerinin belirginleșeceği sonucuna dayanarak toplum içerisinde en s1k görülen bu davranış türünün değişiminin sağlanması son derece önemlidir. Alanyazıyla örtüşmediği nokta olan uyumsuz bilişsel duygu düzenlemeyi yordamaması durumu açısından tartışılması ve yeni çalışmalarla irdelenmesi gerekmektedir. Benzer kavramları incelediği çalışmalarında Silveira, Whitcomb, Pekow, Carbone ve Chasan-Taber (2010), çocukluk ihmal davranışı, duygusal sağlık ve alkol bağımlılığı arasındaki ilişkiyi incelemiş, duygusal ihmale maruz kalan bireylerin duygularını kontrol etmekte güçlük yaşadıklarından dolayı alkole yönelerek bağımlılık kazandıkları sonucuna varmıştır. Bilim'in (2012) çalışmasında ise, duygusal istismar ve ihmal davranışına maruz kalan bireylerin duygusal sağlıklarının zarar gördüğ̈̈ anlaşılmıştır. Bahsi geçen iki çalışma ile bu çalışmadan çıkarılan sonucu birbirinden ayıran nokta uyumsuz davranışa yönelmenin anlamlılık düzeyidir. Duygusal ihmalin uyumsuz bilişsel duygu düzenleme yarattığı ancak farkın anlamlı düzeyde olmadığı ve bu davranışın azaltılması halinde anlamlı düzeyde uyumlu bilişsel duygu düzenleme becerilerinin gelişmesi sonucu alanyazına farklı bir bakış açısı kazandırmıştır. Duygusal istismar alt boyutu, uyumlu ve uyumsuz bilişsel duygu düzenleme üzerinde yüksek yordayıcılık rolü tespit edileceği beklentisiyle çalışmaya dâhil edilmiş ancak sonuçlar beklentiyi ve alanyazını kısmen destekler yönde çıkmıştır.

$\mathrm{Bu}$ çalışmada, otomatik düşüncelerin uyumlu ve uyumsuz bilişsel duygu düzenleme stratejilerini kullanma düzeyleri üzerinde anlamlı bir yordayıcı olduğu tespit edilmiştir. İnsanların çevreye ilişkin saptırılmış düşüncelerinin bir ürünü olarak ortaya çıkan otomatik düşüncelerin bilişsel sağlığı olumsuz etkilediği bilişsel terapinin temel varsayımlarındandır (Beck, 2001). Bilişler vasıtasıyla duyguların düzenlendiği göz önüne alınacak olursa, otomatik düşüncelerin bilişsel duygu düzenleme üzerinde benzer bir etkisi olacağ görülmektedir. 
Depresyona yönelik otomatik düşüncelerin odak noktası kabul edilerek bilişsel duygu düzenleme üzerindeki etkisinin incelenmesi bulguların anlamlılık düzeyini daha net bir şekilde ortaya koymaktadır. Depresif düşüncelerin duygu düzenleme stratejileri ile yakından alakalı olduğunu gösteren çalışmalara alanyazında rastlanmaktadır. Akbulut (2018) uyumsuz duygu düzenleme stratejileri ile depresif düşüncelerin arasında anlamlı ve pozitif yönde bir ilişki olduğunu ortaya koymuştur. Nolen-Hoeksema ve Aldao (2011), çalışmalarında benzer şekilde depresif semptomlar gösteren bireylerin duygu düzenleme güçlügü yaşadığını belirtmişlerdir. Uyumsuz bilişsel duygu düzenleme stratejilerinden "Ruminasyon", depresif düşünceyle iliş̧kilendirilen bir düşünce tarzı olarak aktarılmaktadır (Garnefski vd., 2002). Depresyona dayalı otomatik düşüncelerin ortaya çıkmasında bastırılmış duyguların yarattığı negatif bakış açısının etkisi olduğu bilinmektedir (Nolen-Hoeksema \& Aldao, 2011). Karşılıklı bir etkileşim halinde olduklarını gösteren bulguların alanyazında yer alması ortaya çıkan sonucun geçerliğini desteklemektedir. $\mathrm{Bu}$ araştırmada, üniversite öğrencilerinin maruz kaldıkları örseleyici davranışlar sonucunda geliştirdikleri disosiyatif vb. bozuklukların etkisiyle ölçeklerde gerekli kısımları cevaplandırmış olması muhtemeldir. Birey, yaşadığı istismarın yarattı̆̆ duyguyu bastırmış şekilde ya da istismarı içine alan herhangi bir duruma karşı geliştirdiği kişilik ile cevap veriyor olabilir (Soner ve Aykut, 2017). Ayrıca, toplum baskısı, etiketlenme, aşağılanma gibi unsurların etkisiyle cinsel istismara maruz kalan bireylerin ölçekte yer alan cinsel istismar ile alakalı kısımları gerçeklere dayanarak cevaplandırmamış olabileceği düşünülmektedir. Gelecek çalışmalarda bunun önüne geçmek adına ölçek uygulamasının bireysel olarak yapılmasının daha sağlıklı veriler elde etmeye yardımcı olacağı düşünülmektedir.

Üniversite Öğrencilerinin Bilişsel Duygu Düzenlemelerinde Çocukluk Örselenmeleri ve Otomatik Düşüncelerin Rolü başlıklı çalışmanın yazım sürecinde bilimsel, etik ve alıntı kurallarına uyulmuş; toplanan veriler üzerinde herhangi bir tahrifat yapılmamış, karşılaşılacak tüm etik ihlallerde "Pamukkale Üniversitesi Eğitim Fakültesi Dergisi Yayın Kurulunun" hiçbir sorumluluğunun olmadığı, tüm sorumluluğun Sorumlu Yazara ait olduğu ve bu çalışmanın herhangi başka bir akademik yayın ortamına değerlendirme için gönderilmemiş olduğunu taahhüt ederim. 


\section{Kaynakça}

Akbulut, C. A. (2018). Depresyonun duygu düzenleme süreçlerinin incelenmesi. Klinik Psikiyatri Dergisi, 21, 184-192.

Akduman, G. G., Ruban, C., Akduman, B., ve Korkusuz, İ. (2005). Çocuk ve cinsel istismar. Adli Psikiyatri Dergisi, 3(1), 9-14.

Anderson, C. A., Miller, R. S., Riger, A. L., Dill, J. C., \& Sedikides, C. (1994). Behavioral and characterological styles as predictors of depression and loneliness: review, refinement, and test. Journal of Personality and Social Psychology, 66, 549-558.

Aydın, G., ve Aydın, O. (1990). Otomatik düşünceler ölçeğinin geçerlik ve güvenirliği. Psikoloji dergisi, $7(24), 51-55$.

Beck, C. T. (2001). Predictors of postpartum depression: an update. Nursing Research, 50(5), 275-285.

Bedirhanbeyoğlu H. (2018). Çocukluk çă̆l travmaları, bilişsel duygu düzenleme stratejileri ve riskli davranışlar arasındaki ilişkiler. Yayımlanmış Yüksek Lisans Tezi, Maltepe Üniversitesi Sosyal Bilimler Enstitüsü, İstanbul.

Bilim, G. (2012). Çocukluk çağı örselenme yaşantıları: duygu düzenleme, kişiler arası tarz ve genel psikolojik sağllk açısından bir inceleme. Yayımlanmamış yüksek lisans tezi, Ankara Üniversitesi, Sosyal Bilimler Enstitüsü, Ankara.

Conger, R. D., \& Conger, K. J. (2002). Resilience in Midwestern families: Selected findings from the first decade of a prospective, longitudinal study. Journal of Marriage and Family, 64(2), 361-373.

Cüceloğlu, D. (2015). Insan ve Davranışı. İstanbul: Remzi Kitabevi.

Çelik, H., ve Kocabıyık, O. O. (2014). Genç yetişkinlerin saldırganlık ifade biçimlerinin cinsiyet ve bilişsel duygu düzenleme tarzları bağlamında incelenmesi. Trakya Üniversitesi Eğitim Fakültesi Dergisi, 4(1). 139-155.

Çokluk, Ö., Şekercioğlu, G., ve Büyüköztürk, Ş. (2012). Sosyal bilimler için çok değişkenli istatistik: SPSS ve LISREL uygulamaları (Vol. 2). Ankara: Pegem Akademi.

Demirkap1, E. Ş. (2014). Çocukluk çağl travmalarının duygu düzenleme ve kimlik gelişimine etkisi ve bunların psikopatolojiler ile ilişkisi. Yayımlanmış Yüksek Lisans Tezi, Adnan Menderes Üniversitesi Sosyal Bilimler Enstitüsü, Aydın.

Erdoğan Yıldırım, Z., ve Tekinsav Sütcü, S. (2016). Madde ile ilişkili bozuklukların tedavisinde bilişsel davranış̧̧ grup terapisi etkililiği: Sistematik bir gözden geçirme. Current Approaches in Psychiatry/Psikiyatride Guncel Yaklasimlar, 8(1). 108

Garnefski, N., Kraaij, V., \& Spinhoven, P. (2001). Negative life events, cognitive emotion regulation and emotional problems. Personality and Individual differences, 30(8), 1311-1327.

Garnefski, N., Kraaij, V., \& Spinhoven, P. (2002). Manual for the use of the Cognitive Emotion Regulation Questionnaire. Leiderdorp, The Netherlands: DATEC.

Garnefski, N., Kraaij, V., \& van Etten, M. (2005). Specificity of relations between adolescents' cognitive emotion regulation strategies and internalizing and externalizing psychopathology. Journal of Adolescence, 28(5), 619-631.

Gravetter, F. J., \& Wallnau, L. B. (2016). Statistics for the behavioral sciences. Independence, UK: Cengage Learning.

Gross, J. J. (1998). The emerging field of emotion regulation: an integrative review. Review of general psychology, 2(3), 271-299.

Güler, N., Uzun, S., Boztaş, Z., ve Aydoğan, S. (2002). Anneleri tarafindan çocuklara uygulanan duygusal ve fiziksel istismar/ihmal davranışı ve bunu etkileyen faktörler. $C \ddot{U}$ Tip Fakültesi Dergisi, 24(3), 128-134.

Hollon, S. D., \& Kendall, P. C. (1980). Cognitive self-statements in depression: Development of an automatic thoughts questionnaire. Cognitive therapy and research, 4(4), 383-395. 
Huh, H. J., Kim, K. H., Lee, H. K., \& Chae, J. H. (2017). The relationship between childhood trauma and the severity of adulthood depression and anxiety symptoms in a clinical sample: The mediating role of cognitive emotion regulation strategies. Journal of affective disorders, 213, 44-50.

İdris, K., ve Eroğul, A. R. Ç. (2016). The mediating role of automatic thought and cognitive emotion regulation strategies on relationships among childhood abuse/neglect, behavioral problems and resilience of adolescents. Çukurova Üniversitesi Ë̆itim Fakültesi Dergisi, 45(2), 331-358.

Karagöz, B. (2010). Alkol veya madde băğmlısı bir grupta kendini yaralama davranışının incelenmesi: çocukluk dönemi istismarı ve ihmali ile duygu düzenleme güçlügü faktörleri. Yayımlanmamış Yüksek Lisans Tezi, Hacettepe Üniversitesi Sosyal Bilimler Enstitüsü, Ankara.

Karmiloff-Smith, A. (1995). Beyond modularity: A developmental perspective on cognitive science. Cambridge, US: MIT press.

Kaya, S. (2014). Çocukluk dönemi örselenme yaşantilari ölçeği kısa formu'nun türkçe'ye uyarlanması. Muğla Sıtkı Koçman Üniversitesi Eğitim Bilimleri Enstitüsü Yüksek Lisans Tezi, Muğla.

Kaya, I., \& Çeçen-Erogul, A. R. (2015, February). Relationship between resilience and childhood abuse/neglect in adolescent. In 2nd international conference on education and social sciences (pp. 2-4).

Kendall-Tackett, K., \& Marshall, R. (1998). Sexual victimization of children. Issues in intimate violence, 47-63.

Kılıç, Y. (2016). Cinsel istismar mağduru olan ve olmayan 11 ve 18 yaş arasındaki bir grup klz çocuğunun sosyo-demografik özellikler ve psikolojik belirtiler bakımından karşılaştırılması. Yayımlanmış Yüksek Lisans Tezi, Fatih Sultan Mehmet Vakıf Üniversitesi Sosyal Bilimler Enstitüsü, İstanbul.

Koçyigit, S., Sezer, T., ve Yilmaz, E. (2015). 60-72 Aylık çocukların sosyal yetkinlik ve duygu düzenleme becerileri ile oyun becerileri arasındaki ilişkinin incelenmesi. Hasan Ali Yücel Egitim Fakültesi Dergisi, 12(1), 287.

Meyer, L. B. (2008). Emotion and meaning in music. Chicago, US: University of Chicago Press.

Min, J. A., Yu, J. J., Lee, C. U., \& Chae, J. H. (2013). Cognitive emotion regulation strategies contributing to resilience in patients with depression and/or anxiety disorders. Comprehensive Psychiatry, 54(8), 1190-1197.

Münevver, C. Y., Kızıltepe, G. İ., ve Kandır, A. (2014). Öğretmen adaylarının çocuklardaki fiziksel istismar belirtilerine ilişkin farkındalıkları. Kuramsal Eğitimbilim Dergisi, 7(3), 286-303.

Nolas, S. M. (2015). Children's participation, childhood publics and social change: a review. Children \& Society, 29(2), 157-167.

Nolen-Hoeksema, S., \& Aldao, A. (2011). Gender and age differences in emotion regulation strategies and their relationship to depressive symptoms. Personality and individual differences, 51(6), 704-708.

Onat, O., ve Otrar, M. (2010). Bilişsel duygu düzenleme ölçeğinin Türkçeye uyarlanması: Geçerlik ve güvenirlik çalışmaları. MÜ Atatürk Eğitim Fakültesi Eğitim Bilimleri Dergisi, 31, 123-143.

Peleikis, D. E., Mykletun, A., \& Dahl, A. A. (2005). Current mental health in women with childhood sexual abuse who had outpatient psychotherapy. European Psychiatry, 20(3), 260-267.

Pelendecioğlu, B., ve Bulut, S. (2009). Çocuğa yönelik aile içi fiziksel istismar. Abant İzzet Baysal Üniversitesi Eğitim Fakültesi Dergisi, 9(1). 49-62

Silveira, M. L., Whitcomb, B. W., Pekow, P., Carbone, E. T., \& Chasan-Taber, L. (2016). Anxiety, depression, and oral health among US pregnant women: 2010 Behavioral Risk Factor Surveillance System. Journal of public health dentistry, 76(1), 56-64.

Şanlı, D., ve Öztürk, C. (2012). An analysis of the factors affecting the child rearing attitudes of mothers. Buca Faculty of Education Journal, 32, 31-48.

Orçan, M. (2017). Sosyal gelişsim. Pegem Atıf İndeksi, 126-174. 
Piaget, J. (1964). Part I: Cognitive development in children: Piaget development and learning. Journal of Research in Science Teaching, 2(3), 176-186.

Soner, S., ve Aykut, S. (2017). Dissosiyatif kimlik bozukluğu temelinde sosyal bir sorun: ensest ve sosyal hizmet. Türkiye Sosyal Hizmet Araştırmalarl Dergisi, 128-141.

Taner, Y., ve Gökler, B. (2004). Çocuk istismarı ve ihmali: Psikiyatrik yönleri. Acta Medica, 35(2), 8286.

Thompson, R. A. (1991). Emotional regulation and emotional development. Educational Psychology Review, 3(4), 269-307.

Tıraşçı, Y., \& Gören, S. (2007). Çocuk istismarı ve ihmali. Dicle Tıp Dergisi, 34(1), 70-74.

Turhan, E., Sangün, Ö., ve İnandı, T. (2006). Birinci basamakta çocuk istismarı ve önlenmesi. Sürekli Tip Ĕgitimi Dergisi (Sted). 15(9), 153-157

World Health Organization. (2002). The world health report 2002: reducing risks, promoting healthy life. World Health Organization.

Yeşilyaprak, B. (1993). Kişilik gelişiminde ailesel faktörlerin etkisine ilişkin bir araştırma. Sosyal Politika Çalışmaları Dergisi, 3(3). 3-16

Yıldız, M. (2017). Ergenlerde Olumsuz Otomatik Düşüncelerin Sosyal Becerilere Etkisi. Uluslararası Güncel Eğitim Araştırmaları Dergisi, 3(1), 45-55.

Young, J. E., Klosko, J. S., \& Weishaar, M. E. (2003). Schema therapy: A practitioner's guide. NewYork, US: Guilford Press. 


\section{Extended Abstract}

\section{Introduction}

Cognitive emotion regulation is defined as the elimination of distressing emotional and physical life experiences using cognitive strategies (Garnefski, Kraaij \& Spinhoven, 2001). Emotional wellbeing is associated with experiences through life. Early childhood experiences can be accepted as most crucial ones. Emotional and physical development takes form based on parents' attitudes and behaviors. Different methods in child raising sometimes cause maltreatments. Physically, emotionally and sexually maltreated children can have compulsions in emotion regulations. In relation to that, lifetime interpersonal relationships create automatic thoughts. Cognitive emotion regulation capability seems related to these two concepts, child maltreatment and automatic thoughts. In this research, it is aimed to determine university students' cognitive emotion regulations in relation to childhood traumatic experiences and automatic thoughts.

\section{Method}

This research is conducted with descriptive survey model. The data gathered from 652 undergraduate students who was studying in different faculties of Zonguldak Bülent Ecevit University in 2017-2018 academic year. To investigate the main aspects of this research, Cognitive Emotion Regulation Scale which was developed by Onat and Otrar (2010), Childhood Traumatic Experiences Scale Short Form which was developed by Kaya (2014), and Automatic Thoughts Scale which was developed by Aydın and Aydın (1990) were used. All statistics were calculated by use of SPSS 23.0. All data were analyzed whether distribution is normal or not. It was calculated that data has a normal distribution. For this reason, parametric statistical tests were used to examine the effects of university students' childhood traumatic experiences and automatic thoughts on cognitive emotion regulation.

\section{Results and Discussion}

According to the analysis, it was suggested that compatible emotion regulation can be predicted significantly by automatic thoughts and emotional neglect. The other sub-dimensions of child maltreatment don't predict compatible emotion regulation. On the other hand, it was calculated that university students' experienced emotional abuse, physical neglect and child maltreatment in general and automatic thoughts are significantly predicts their incompatible emotion regulations. Contrary to this, sexual abuse and physical abuse weren't calculated as a significant predictor of incompatible emotion regulation. When the researches which have related topics are reviewed, there are many supportive researches can be found in literature. Huh, Kim, Lee and Chae made a research which is about the relationship between emotion regulation and childhood traumatic experiences have conclusions that there is a significant relationship between these two concepts. Bilim (2012) also suggested that there is a negative and significant relationship between cognitive emotion regulation and childhood traumas. In this research, it was found that physical abuse doesn't' have any significant prediction on both compatible and incompatible emotion regulation. The level of physical abuse determines the effect on minds. As in this research, Güler, Uzun, Boztaş and Aydoğan (2002), determined and examined parents which abuse their children physically but when it comes to analyze children, it was hard to find effect as much as the abuse. 
In this research, emotional abuse significantly predicts only incompatible emotion regulation in a positive way. In his research Karagöz (2010), also found a close conclusion that people who exposed to emotional abuse have a tendency to hurt themselves and addict drugs. It can be seen that there are related researches about the relationship between all types of child abuse and cognitive emotion regulation and most of them have similar conclusions as this research. Finally, automatic thoughts were calculated as significant predictors of university students compatible and incompatible emotion regulations. Depressive automatic thoughts always seem effective on cognitive health. It is also one of basic assumptions of cognitive theory (Beck, 2001). Not only in theorists but also other researchers has emphasized on this relationship. Akbulut (2018), presented results which includes that there is a significant relationship between depressive thoughts and emotion regulation also supports this research. According to all analysis made in this research, it can be seen that emotion regulation capability might weaken or stronger depending on the issues in life. 